\title{
The Potential of Cassava (Manihot esculenta Crantz) Peels as an Organic Fertilizer
}

\author{
Onguene Dieudonne*, Nguefack Julienne, Joseph Blaise Dongmo Lekagne, \\ Charles Dakole Daboy, Ndonkeu Mangoumou Ghislaine \\ Department of Biochemistry, University of Yaounde I, Cameroon \\ Received: 20 September 2020 / Revised: 28 December 2020 / Accepted: 13 January 2021 / Published: 19 January 2021
}

*Corresponding author email: onguened@gmail.com

\begin{abstract}
Cassava peels are in large quantity and practically of no economic value in many developing nations such as Cameroon, where cassava is widely consumed and processed far beyond other crops. Cassava peels might be used in those countries to face declining soil fertility and soil erosion. This study aimed to evaluate the composting of cassava peels and the effect of the increasing quantity of cassava peels in the bin during the process of composting and to assess some physico-chemical qualities, biological properties and the phytotoxicity of the produced composts. After three months of composting the produced composts (C1; C2; C3 and C4) had a dark brown color, relatively dry, uniform structure and its texture were similar to the soil's texture. The electrical conductivity of the various composts was in between 1499 and $1924 \mu \mathrm{S} . \mathrm{cm}^{-1}$. The $\mathrm{pH}$ (6.50-6.73), was slightly acid, favorable for the cultivation of sweet pepper. The composts were rich in minerals $\left(\mathrm{Mg}^{2+} ; \mathrm{Ca}^{2+} ; \mathrm{K}^{+}\right.$; and $\left.\mathrm{Na}^{+}\right)$and poor in heavy metals such as $(\mathrm{Cu}, \mathrm{Zn}$ and $\mathrm{Mn})$. The composts $\mathrm{C} / \mathrm{N}$ ratios were between 13.15 to 13.42 . The produced composts showed a germination index and the rate of germination higher than $80 \%$ at all amounts, indicating the absence of phytotoxicity. The increased amounts of cassava peels did not alter the process of composting and increased the fungal and bacterial populations. In conclusion, cassava peels are good substrates that can be used to produce stable and inclusive organic fertilizers, with high nutrient content, and less hazardous material which could be used in farms to remediate declining soil fertility and to promote sustainable agriculture.
\end{abstract}

Keywords : Cassava peels, compost, phytotoxicity, sustainable agriculture.

\section{Introduction}

Cassava (Manihot esculenta Crantr, Euphorbiaceae) is the sixth most important food crop globally, in terms of annual production, and is a staple food for approximately 800 million people [1]. This perennial root crop is grown in the tropics, including sub-Saharan Africa, Asia, the Pacific Islands, and Central and South America [1]. Cassava is cultivated in more than 100 countries worldwide [2]. It holds the position of the strategic crop in many tropical countries, [2] such as Cameroon. In Cameroon, it is a leading crop in terms of annual yield both for cash and food crop categories. It is widely consumed and processed far beyond other crops such as maize and rice [2]. Cassava is cultivated for its starchy roots and is a staple food material in many developing countries, including Cameroon, where it is eaten as garri, fufu, or other products. According to the Central Bureau of Statistics in 2004-2008, the production of cassava peel tend to increase annually which means the production of cassava peel also increasing [3]. Cassava peel is the peeling of food product from cassava. The Chemical composition of cassava peel is identic with cassava which contains most of the polysaccharide and some of mineral and water. 
The main component of polysaccharide is amylose, amylopectin, and cellulose [3]. Cassava peel represents about 5 to $15 \%$ of the root when peeled mechanically [4] and about $20-35 \%$ of the weight of the tuber with hand peeling [5]. The solid fibrous dry waste consists of $56-60 \%$ starch, $15-18 \%$ hemicellulose, $2-3 \%$ lignin, $1.5-2 \%$ protein, $2 \%$ pentosan and $0.4-5 \%$ reducing sugar [6] making it a good organic matter of composting. During the processing of cassava tubers, an enormous quantity of cassava peels (about $30 \%$ of processed cassava tubers) are generated as waste [7] and only an insignificant proportion is usually fed to livestock such as goats [8]. Very often, cassava peels are thrown away after removal from the edible part of the root during processing. The peel eventually decays in the soil [9].

However, The potential of these peels to be used in the production of other products such as biofertilizers can help most of the cassava processors and farmers to increase their source of income, to avoid the environmental nuisance released by cassava peels on dumping sites and the pollution of both water and land resources, which might increases rodents and insect vector diseases thereby creating public health nuisance. This study therefore aimed at assessing some physico-chemical qualities and biological properties of the produced composts from cassava peels, to determine if respectively, the composting of cassava peels without any additional material and the increased quantity of cassava peels in the bin during the process of composting might undermine the process of composting and finally to assess the phytotoxicity of the produced composts.

\section{Materials and Methods}

\subsection{Compost Preparation}

Fresh cassava peels were collected from various sources within the subregion of Yaounde (Cameroon). The obtained cassava was air-dried for one week. Then the dried cassava peels were mechanically ground in a local mill to particles ranging $0.1-1.5 \mathrm{~mm}$. Figure 1 and 2 respectively below present cassava peels before and after shredding.

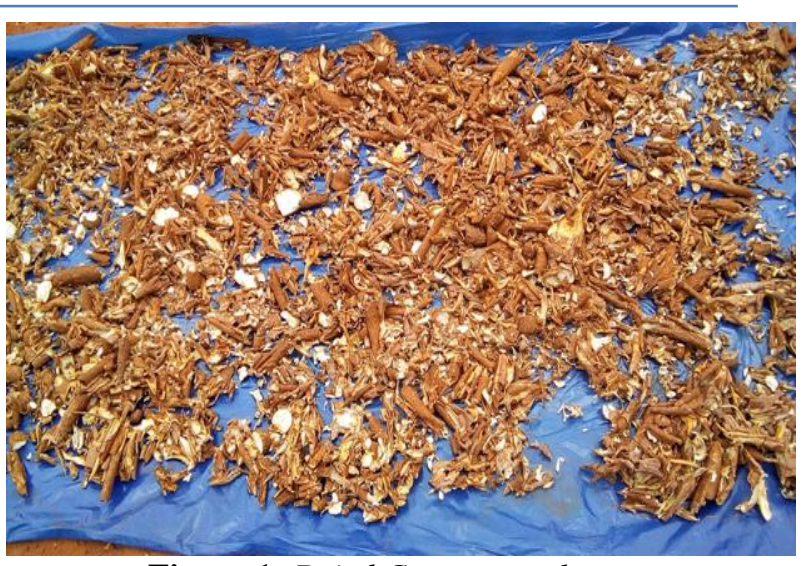

Figure 1: Dried Cassava peels.

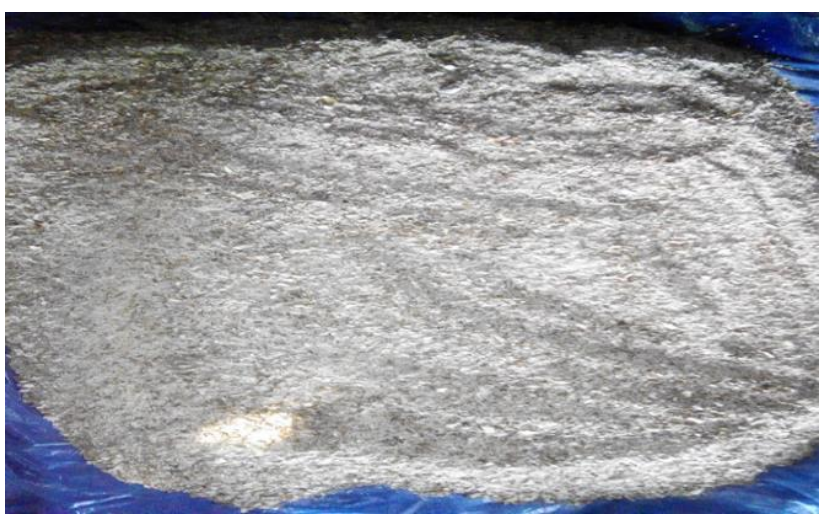

Figure 2: Cassava peels after shredded.

\subsection{Properties of input materials}

For comparative purposes, four (4) types of compost in a different weight of $50 \mathrm{~kg}, 70 \mathrm{~kg}, 90 \mathrm{~kg}$ and $110 \mathrm{~kg}$ of cassava peels were produced, labelled C1, C2, C3 and C4 respectively. Table1 shows the nutrient composition of cassava peels.

\subsection{Study area}

Field experiments were carried out at the University of Yaounde I. The average air temperature varies from 20 to $23^{\circ} \mathrm{C}$. It is governed by a "Cameroonian" climate, which is very hot and humid.

\subsection{Online monitoring of the composting}

The process of composting was carried out in composting bins (barrels) of 120 litres for 3 months. The experiment was a randomized block design with three replicates. The temperature was measured weekly for the whole composting period [10]. To prevent excessive heat loss during composting, the barrels were wrapped with plastic tilt. Additional holes were cut around the barrels to provide improved aeration and were 
Onguene Dieudonne et al., Int. Ann. Sci.; Vol. 10, Issue 1, pp: 107-117, 2021

turned once after two weeks to ensure adequate $\mathrm{O}_{2}$ levels inside the barrels. The temperature was monitored at a depth of $65 \mathrm{~cm}$ inside the piles at 9:00 h twice every two weeks. The water content of barrels was maintained at $60 \%$ of their water holding capacity throughout the 3-months experiment and water was added depending on the level of humidity, after barrels were turned. The compost was matured by the end of the 12th weeks and the temperature dropped and remained unchanged with the compost having no peculiar smell. At the end of the composting process, three subsamples were taken randomly from within each barrel, they were bulked and homogenised, air-dried and stored for some physico chemicals, biological properties, and phytotoxicity analysis.

\subsection{Physical and chemical analysis}

The determination of moisture content of cassava peels was run according to the method of [11]. Cassava peels were dried at $105^{\circ} \mathrm{C}$ for 4 hours until constant weight. The emptied Petri dishes have been heated and weighted then $10 \mathrm{~g}$ of samples was introduced in each petri dish and the whole was also weighted. The next step consisted of putting the petri dishes containing cassava peels in the oven at $105^{\circ} \mathrm{C}$ during 4 hours, then after 4 hours, they have been transferred into a desiccator. After 05 minutes of cooling the whole has been weighted and the moisture content was calculated as the following formula:

$$
\text { Moisture content }=(\mathrm{A}-\mathrm{B} / \mathrm{B}-\mathrm{C}) \times 100
$$

A : Weight of petri dishes and sample before drying.

B: Weight of the petri dishes and the sample after drying.

C: Weight of the emptied petri dishes

Nutrients (P, K, Ca, Mg, and $\mathrm{Na}$ ) and heavy metal ( $\mathrm{Mn}, \mathrm{Cu}$, and $\mathrm{Zn}$ ) contents were determined after wet digestion by inductively coupled plasma atomic emission spectroscopy (ICP-AES). The $\mathrm{pH}$ measurement was carried out according to the international standard ISO 10390 (1994). 10 $\mathrm{g}$ of compost was weighed and introduced into an Erlenmeyer flask containing $50 \mathrm{ml}$ of distilled water; then the mixture was stirred for 5 minutes and then allowed to stand for 2 hours. After standing, the $\mathrm{pH}$ was then measured using a HQ $11 \mathrm{D}$ brand $\mathrm{pH}$ meter.

To measure electrical conductivity, $20 \mathrm{~g}$ of compost were introduced into $100 \mathrm{ml}$ of distilled water, stirred for 30 minutes and then filtered. The specific electrical conductivity of the filtered extract was measured using a Hach HQ conductivity meter 14d. (NF ISO 11265, 2005). The methods below were used to determine an Organic C (Corg) and total N.

$50 \mathrm{~g}$ of compost were dried in an oven at $105^{\circ} \mathrm{C}$ and then calcined at $550{ }^{\circ} \mathrm{C}$ for 2 hours in an oven. The percentage of total organic matter $(\%$ MOT) or of volatile solid was obtained by the difference in weighing between the mass of the sample dried at $105{ }^{\circ} \mathrm{C}$ and the mass of the sample after calcination [12] according to this formula:

$$
\% \operatorname{MOT}=\frac{(\mathrm{M} 1-\mathrm{M} 2)}{\mathrm{M} 1} \times 100
$$

M 1: a mass of the sample after heating in the oven $(\mathrm{g})$;

M 2: a mass of the sample after calcination (g); $-\%$ MOT: percentage of dry matter content in the sample.

Total organic carbon was determined according to the formula below:

$$
\% \mathrm{C}=\frac{(\% \mathrm{MOT})}{2}
$$

The total organic nitrogen content was determined by the Kjeldahl method. The mineralized sample is distilled with $40 \%$ sodium hydroxide in a BUCHI K-350 nitrogen distiller. The nitrogen vapours obtained are collected in an Erlenmeyer flask containing a pinkish color mixture composed of $20 \mathrm{ml}$ of $3 \%$ boric acid and 3 drops of Tashiro reagent. This mixture gradually turns yellowish-green in the case where the distilled sample contains nitrogen, as the sample drops from the distillation column are added. The solution obtained was assayed by titrimetry with $0.1 \mathrm{~N}$ sulfuric acid. 
The C / N ratio of the composts was calculated from the organic carbon and nitrogen values obtained. It was determined according to the formula below:

$$
C / N=\frac{\text { percentage of organic carbon }}{\text { percentage of total nitrogen }}
$$

\subsection{Phytotoxicity test}

To evaluate the compost maturity and their phytotoxicity, a germination index and germination test were conducted with sweet pepper seeds (yelo wonder) according to respectively [13] and the method using soil (compost) of [14]

\subsubsection{Germination Index}

Compost extracts were prepared by shaking compost samples with distilled water at three different dilutions $(10 \%, 30 \%$ and $50 \%$ ) in a wrist-action shaker for $20 \mathrm{~min}$ at $416 \mathrm{rpm}$, followed by filtering the slurry through filter paper (Whatman). The germination test was carried out (in triplicate) on filter paper in petri dishes. Sweet pepper seeds were placed onto filter paper, ten millilitres of aqueous extract from composts were added to dishes and the dishes were placed in the dark at $25^{\circ} \mathrm{C}$. Petri dishes with sweet pepper seeds and sterile distilled water (10 $\mathrm{mL}$ ) was the control. The germination percentages with respect to control and relative root lengths were determined after 14 days. The GI was calculated as GI $=\% \mathrm{G} \times \mathrm{Le} / \mathrm{Lc}$, where $\% \mathrm{G}$ is the percentage of germinated seeds in each extract with respect to control, Le is the mean total root length of the germinated seeds in each extract and Lc is the mean root length of the control. The control GI value is considered as $100 \%$. Seeds were considered to be germinated if the radicle was $5 \mathrm{~mm}$ long [15].

\subsubsection{Germination test}

For comparative purposes and to estimate the value of the composts, four types of composts, sampled from the produced composts, in proportion of $1 \mathrm{~kg}, 2 \mathrm{~kg}, 4 \mathrm{Kg}$ and $6 \mathrm{~kg}$ were introduced respectively in four buckets of 10 litres labelled B1, B2, B3 and B4 with three replications. The bottoms of each bucket was aerated with five holes .Then, 400 seeds of sweet pepper in replicates of 100 were randomly counted from the well-mixt pure seed. Afterward, replicates were divided into split replicates of 50 seeds to ensure adequate spacing and were sown concentrically in each bucket. After that, all the treatments were placed in direct sunlight (temperature: $25^{\circ} \mathrm{C}$ ). The buckets were continuously watered with distilled water $(\mathrm{pH}$ : 6.5), in accordance to the moisture content of the composts, during the test period to avoid composts to be dried out. The first count of the germination seed started after 7 days and the final count after 14 days. The rate of the germination test was calculated as the average of 400 seeds replicates and the below formula was used:

$$
\begin{aligned}
& \text { rate of the germination } \\
& =\frac{\text { number of germinated seeds }}{\text { number of seeds sown }} \times 100
\end{aligned}
$$

\subsection{Microbiological analysis}

The analysis of mycoflora was carried out according to the suspensions-dilutions technique [16], on medium agar Potato dextrose agar (PDA) added to an antibiotic (Gentamicin). In a $250 \mathrm{ml}$ Erlenmeyer flask containing $90 \mathrm{ml}$ of distilled water sterile, $10 \mathrm{~g}$ of dry compost was added aseptically (after drying at $30^{\circ} \mathrm{C}$ overnight). This mixture was stirred mechanically with magnetic bars for 30 minutes to suspend the compost particles and the spores and mycelia attached thereto. The suspension obtained corresponds to the $10^{-1}$ dilution. $1 \mathrm{ml}$ of the $10^{-1}$ dilution was removed aseptically and put in $9 \mathrm{ml}$ of sterile distilled water thus giving the $10^{-2}$ dilution which was stirred for two minutes before taking $1 \mathrm{ml}$ which was added to $9 \mathrm{ml}$ of water sterile distilled and so on until dilution $10^{-8} .0 .1 \mathrm{ml}$ was taken from each dilution, operating from $10^{-8}$ dilution to the $10^{-1}$ dilution, and seeded onto the culture media, using a sterile glass bent pipette. Petri dishes were incubated at $26^{\circ} \mathrm{C}$ for 3 days. The fungal load was determined by colony counting and the results were expressed in CFU (Colony Forming Units) / g of compost according to the mathematical formula below.

$$
N=\frac{\sum \text { colonies }}{2 \operatorname{Vml} \mathrm{x}(\mathrm{n} 1+0.1 \mathrm{n} 2)} \times \mathrm{d} 1
$$


Onguene Dieudonne et al., Int. Ann. Sci.; Vol. 10, Issue 1, pp: 107-117, 2021

$\mathrm{N}$ : Number of CFU per gram of compost; $\Sigma$ colonies: Sum of colonies of interpretable petri dishes; V: Volume of solution deposited $(1 \mathrm{ml})$; $\mathrm{n} 1$ : Number of petri dishes considered at the first dilution retained; n2: Number of petri dishes considered at the second dilution retained; $\mathrm{d} 1$ : Factor of the first dilution retained. Only Petri dishes counting between 15 and 150 colonies at two successive dilutions were selected for enumeration [17] [18].

The determination of the total bacterial flora was carried out according to the technique of suspensions-dilutions on solid medium, nutrient agar added to an antifungal agent: $0.5 \%$ nystatin. $5 \mathrm{~g}$ of each compost was placed in a $100 \mathrm{ml}$ Erlenmeyer flask containing $45 \mathrm{ml}$ of sterile physiological saline ( $9 \mathrm{~g}$ of $\mathrm{NaCl} / \mathrm{L}$ of distilled water) and suspended with a magnetic stirrer for 30 minutes. The suspension was then decanted for 20 minutes, then the supernatant was removed, and it constitutes the $10^{-1}$ dilution. From this suspension, decimal dilutions were made up to $10^{-8}$. $0.1 \mathrm{ml}$ was taken from each dilution, operating from $10^{-8}$ dilution to $10^{-1}$ dilution, and seeded onto the culture media, using a sterile glass bent pipette. The petri dishes were incubated at $30{ }^{\circ} \mathrm{C}$ for 24 hours [17].

\subsection{Statistical analyses}

The data obtained were subjected to a two-way analysis of variance (ANOVA) followed by a Tukey's B-test at 5\% level. The data were analysed using SPSS Software Package 16.

\section{Results}

\subsection{Produced composts}

The composting of the above different treatments lasted 3 months. The produced composts (C1, C2, C3, and C4) were odourless during the composting process and presented the same odour (they did not have a smell of ammonia) at the end of composting. They had a dark brown color, relatively dry and uniform structure and its texture was similar to the soil's texture. Their temperature was $25{ }^{\circ} \mathrm{C}$. Figure 3 below presents the obtained composts.

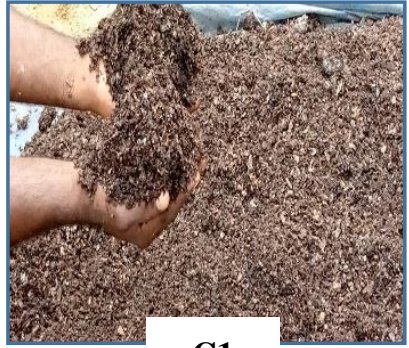

C1

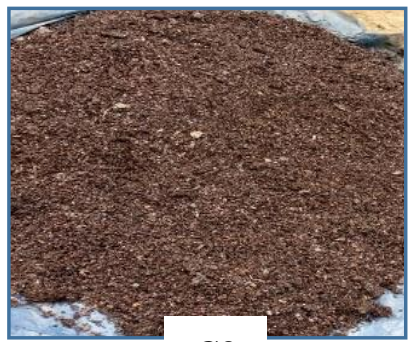

C3

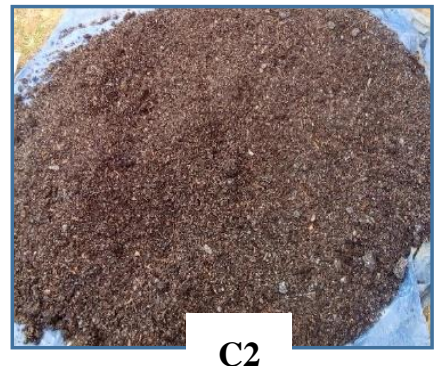

$\mathrm{C2}$

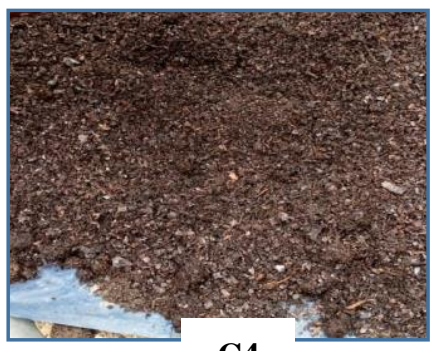

C4
Figure 3: Composts produced from the different weights of cassava peels.

\subsection{Material characteristics}

The physical, chemical properties and the micronutrients content of the Cassava peels are reported in Table 1.

Table 1: Physical and chemical properties of cassava peels

\begin{tabular}{|l|c|}
\hline \multicolumn{1}{|c|}{ Parameters } & Cassava peels \\
\hline $\mathrm{pH}$ & 5.7 \\
\hline Organic carbon $(\%)$ & 44.3 \\
\hline Total nitrogen $(\%)$ & 1.47 \\
\hline Total phosphorus $(\mathrm{g} / \mathrm{kg})$ & 7.9 \\
\hline Total potassium $(\mathrm{g} / \mathrm{kg})$ & 1.1 \\
\hline total calcium $(\mathrm{g} / \mathrm{kg})$ & 18.9 \\
\hline Total magnesium $(\mathrm{g} / \mathrm{kg})$ & 8.1 \\
\hline total sodium $(\mathrm{g} / \mathrm{kg})$ & 0.12 \\
\hline Moisture $(\%)$ & 2.43 \\
\hline C/N & 30.13 \\
\hline
\end{tabular}

\subsection{Physical and chemical properties}

The physical and chemical properties and the micronutrients content of the produced composts are reported in Table 2 and 3.

At the end of the composting, the $\mathrm{pH}$ of $\mathrm{C} 1, \mathrm{C} 2$, C3 and C4 was in between 6.50 to 6.73, which slightly increased compare to the $\mathrm{pH}$ (5.7) of cassava peels. There was not a significant difference between the $\mathrm{pH}$ of the obtained composts. The total nitrogen $(2.68 \%)$ of the first compost (C1) was not significantly higher than 
The Potential of Cassava (Manihot esculenta Crantz) Peels as an Organic Fertilizer

the total nitrogen of the initial subtracts. Also, the total nitrogen (respectively 5.30\%, 8.1\%, and $10.50 \%$ ) of the last three compost significantly increased at the end of the process. The same fashion is reflected concerning the percentage of the organic carbon, in which the organic carbon of C2 $(70.5 \%)$, C3 $(105.75 \%)$ and C4 (141\%) dramatically increased. There was respectively a significant difference between the percentage of organic carbon of cassava peels (44.3\%), C1 $(35.25 \%)$, and the last three compost (C2, C3 and C4). On the other hand, the proportion of the total potassium of each produced composts increased significantly and was respectively 5.63 mg.kg-1, 11.25 mg.kg-1, 16.23 mg.kg-1, and 22.49 mg.kg-1; while the percentage of the total phosphorus of the each produced compost, which was respectively C1 (130 mg.kg-1), C2 (240 mg.kg-1), C3 (380 mg.kg-1), and C4 (500), gradually decreased with the increase among of cassava peels. The ratio $\mathrm{C} / \mathrm{N}$ Of the four cassava peels manure has significantly decreased. The value of those ratios was between 13.15 and 13.4, and there was not a great difference in between the ratio $\mathrm{C} / \mathrm{N}$ of the produced composts. However, the EC slightly increased with the among of cassava peels that was composted and the difference was not significant. The concentration of $\mathrm{Mg}, \mathrm{Ca}, \mathrm{K}, \mathrm{Na}, \mathrm{Mn}$ and $\mathrm{Cu}$ gradually increased with the increase among of cassava peels. The concentration of the four composts in terms of $\mathrm{Zn}$ fluctuated in between 0.025 and 0.03 g.kg- 1 .

\subsection{Phytotoxicity}

\subsubsection{Germination Index (GI)}

Figure 2 shows that cassava peels-based composts were not toxic to the sweet pepper seeds and seedlings at the concentration of $10 \%$ $30 \%$ and 50\%. All extracts, C1, C2, C3, and C4, had a germination index between $80 \%$ to $84.4 \%$, and the difference was not significantly different.

Table 2: $p H, C, N, P, C$ and $C / N$ of the produced composts made with increasing $K g$ of cassava peel.

\begin{tabular}{|c|c|c|c|c|c|c|}
\hline \multirow[b]{2}{*}{ composts } & \multicolumn{6}{|c|}{ Parameters } \\
\hline & $\mathrm{pH}$ & $\begin{array}{l}\text { Total nitrogen } \\
(\%)\end{array}$ & $\begin{array}{l}\text { Total phosphorus } \\
\left(\text { mg.kg- }^{1}\right)\end{array}$ & $\begin{array}{l}\text { Total potassium } \\
\left(\mathrm{mg} \cdot \mathrm{kg}_{-}{ }^{1}\right)\end{array}$ & $\begin{array}{c}\text { Organic carbon } \\
(\%)\end{array}$ & $\mathrm{C} / \mathrm{N}$ \\
\hline $\mathrm{C} 1$ & $6.50 \pm 0.12^{\mathrm{a}}$ & $2.68 \pm 0.34^{\mathrm{a}}$ & $130 \pm 0.09^{a}$ & $5.63 \pm 1.34^{\mathrm{a}}$ & $35.25 \pm 2.62^{a}$ & $13.15^{\mathrm{a}}$ \\
\hline $\mathrm{C} 2$ & $6.61 \pm 0.20^{\mathrm{a}}$ & $5.30 \pm 0.99^{b}$ & $240 \pm 0.16^{b}$ & $11.25 \pm 2.67^{b}$ & $70.5 \pm 4.24^{\mathrm{b}}$ & $13.30^{\mathrm{a}}$ \\
\hline $\mathrm{C} 3$ & $6.68 \pm 0.14^{\mathrm{a}}$ & $8.01 \pm 0.03^{c}$ & $380 \pm 0.26^{c}$ & $16.23 \pm 3.85^{c}$ & $105.75 \pm 3.86^{\mathrm{c}}$ & $13.20^{\mathrm{a}}$ \\
\hline $\mathrm{C} 4$ & $6.73 \pm 0.11^{\mathrm{a}}$ & $10.50 \pm 0.05^{\mathrm{d}}$ & $500 \pm 0.20^{d}$ & $22.49 \pm 5.33^{\mathrm{d}}$ & $141 \pm 5.48^{\mathrm{d}}$ & $13.42^{\mathrm{a}}$ \\
\hline
\end{tabular}

Means followed by the same letter in a column are not significantly different at $\mathrm{P} \leq 0.05$

Table 3: EC, extractable nutrients and heavy metal content of the produced composts made with increasing Kg of cassava peel.

\begin{tabular}{|l|c|c|c|c|c|c|c|c|}
\hline \multirow{2}{*}{ composts } & \multicolumn{9}{|c|}{ Parameters } \\
\cline { 2 - 9 } & $\begin{array}{c}\mathrm{EC} \\
\left(\mu \mathrm{S} . \mathrm{cm}^{-1}\right)\end{array}$ & $\begin{array}{c}\mathrm{Mg} \\
(\mathrm{mg} \cdot \mathrm{kg}-1)\end{array}$ & $\begin{array}{c}\mathrm{Ca} \\
(\mathrm{mg} \cdot \mathrm{kg}-1)\end{array}$ & $\begin{array}{c}\mathrm{K} \\
(\mathrm{mg} \cdot \mathrm{kg}-1)\end{array}$ & $\begin{array}{c}\mathrm{Na} \\
(\mathrm{mg} \cdot \mathrm{kg}-1)\end{array}$ & $\begin{array}{c}\mathrm{Mn} \\
(\mathrm{g} \cdot \mathrm{kg}-1)\end{array}$ & $\begin{array}{c}\mathrm{Cu} \\
(\mathrm{g} \cdot \mathrm{kg}-1)\end{array}$ & $\begin{array}{c}\text { Zin } \\
(\mathrm{g} \cdot \mathrm{kg}-1)\end{array}$ \\
\hline $\mathrm{C} 1$ & $1499 \pm 210.86^{\mathrm{a}}$ & $0.04 \pm 0.01^{\mathrm{a}}$ & $0.24 \pm 0.12^{\mathrm{a}}$ & $5.63 \pm 1.23^{\mathrm{a}}$ & $2.38 \pm 0.50^{\mathrm{a}}$ & $0,10 \pm 1,11^{\mathrm{a}}$ & $5.53 \pm 1.16^{\mathrm{a}}$ & $0,028 \pm 0,01^{\mathrm{a}}$ \\
\hline $\mathrm{C} 2$ & $1737 \pm 211.70^{\mathrm{b}}$ & $0.07 \pm 0.03^{\mathrm{b}}$ & $0.48 \pm 0.19^{\mathrm{b}}$ & $11.26 \pm 1.30^{\mathrm{b}}$ & $3.58 \pm 0.29^{\mathrm{b}}$ & $0,11 \pm 1,01^{\mathrm{b}}$ & $8.20 \pm 0.30^{\mathrm{b}}$ & $0,026 \pm 0,014^{\mathrm{a}}$ \\
\hline $\mathrm{C} 3$ & $1830 \pm 187.74^{\mathrm{c}}$ & $0.11 \pm 0.04^{\mathrm{c}}$ & $0.73 \pm 0.23^{\mathrm{c}}$ & $16.80 \pm 2.01^{\mathrm{c}}$ & $7.58 \pm 2.21^{\mathrm{c}}$ & $0,12 \pm 1,21^{\mathrm{c}}$ & $12.56 \pm 0.23^{\mathrm{b}}$ & $0,025 \pm 0,011^{\mathrm{a}}$ \\
\hline $\mathrm{C} 4$ & $1924 \pm 199.84^{\mathrm{d}}$ & $0.15 \pm 0.02^{\mathrm{d}}$ & $0.94 \pm 0.29^{\mathrm{d}}$ & $22.49 \pm 0.54^{\mathrm{d}}$ & $8.59 \pm 0.40^{\mathrm{d}}$ & $0,14 \pm 1,15^{\mathrm{d}}$ & $20.32 \pm 2.35^{\mathrm{d}}$ & $0,03 \pm 0,012^{\mathrm{b}}$ \\
\hline
\end{tabular}

Means followed by the same letter in a column are not significantly different at $\mathrm{P} \leq 0.05$ 


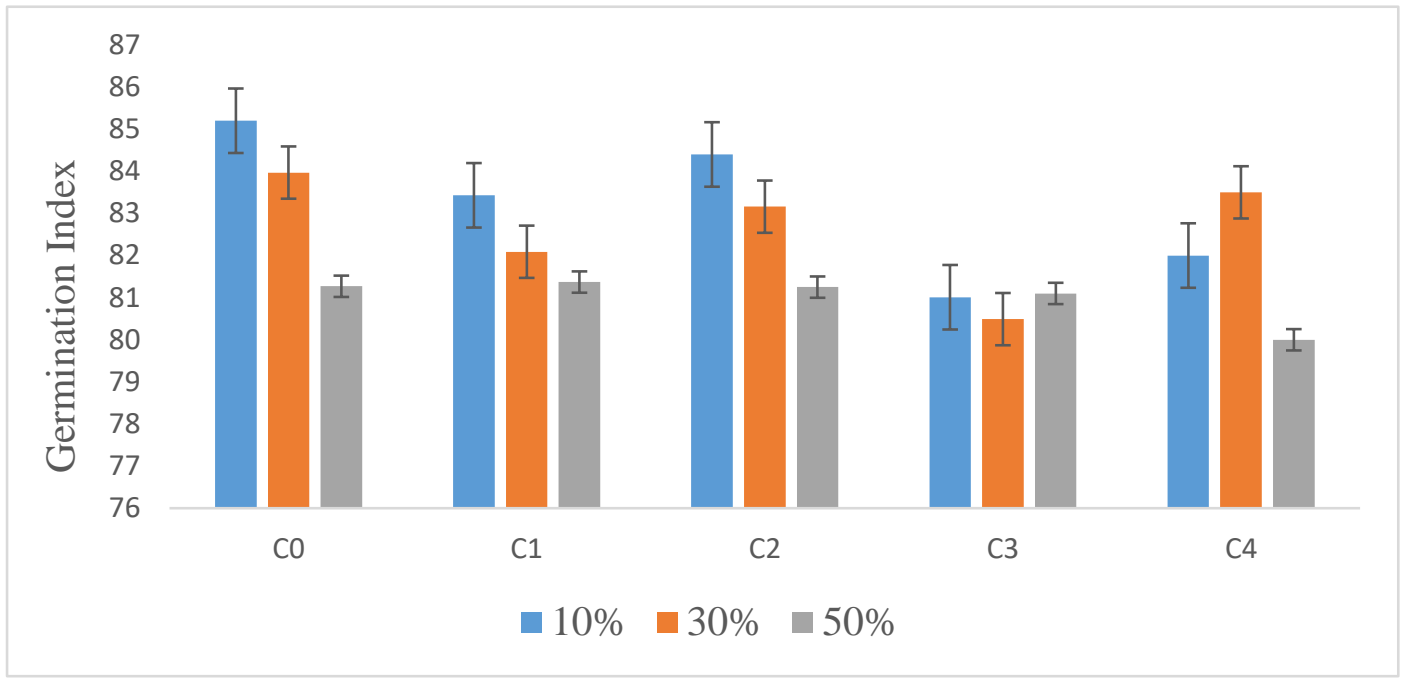

Figure 2: Germination index in cassava peels-based composts made with increasing percentages of the quantity of cassava peels.

\subsubsection{Germination test}

Table 4 illustrated and confirmed that all the samples of the composts were not toxic to the sweet pepper seeds and seedlings respectively at the proportion of $1 \mathrm{~kg}, 2 \mathrm{~kg}, 4 \mathrm{~kg}$, and $6 \mathrm{~kg}$, which had the rate of germination in between 96 and $99 \%$.

Table 4: The rate of germination (\%) of sweet peppers seeds

\begin{tabular}{|c|c|}
\hline $\begin{array}{c}\text { Samples of the } \\
\text { composts }\end{array}$ & The rate of germination (\%) \\
\hline B1 & $97 \pm 4.2^{\mathrm{a}}$ \\
\hline B2 & $96 \pm 4.8^{\mathrm{a}}$ \\
\hline B3 & $99 \pm 4.7^{\mathrm{a}}$ \\
\hline B4 & $97 \pm 4.9^{\mathrm{a}}$ \\
\hline
\end{tabular}

Means followed by the same letter in a column are not significantly different at $\mathrm{P} \leq 0.05$

\subsection{Biological properties}

The increased of the amount of cassava peels did not negatively impair the concentration of fungal and bacterial population. There was not a significant difference respectively in between the concentration of bacterial and fungal biomass from C1, C2, C3, and C4 (Table 5). However, the proportion of fungi biomass was greater than the proportion of bacterial, which was respectively in between 88.2 to $89.3 \times 10^{5}$ UFC.g- 1 compost for fungi population and 71.9 to $74.1 \times 10^{5}$ UFC.g-1 compost for the bacterial population.
Table 5: Microbial biomass counted in compost samples.

\begin{tabular}{|c|c|c|}
\hline \multirow{2}{*}{ Treatment } & \multicolumn{2}{|c|}{$\begin{array}{c}\text { Microbial biomass } \\
\left(.10^{5} \text { UFC.g-1 compost }\right)\end{array}$} \\
\cline { 2 - 3 } & Fungi & Bacteria \\
\hline C1 & $88.6 \pm 1.49^{\mathrm{a}}$ & $71.9 \pm 6.27^{\mathrm{a}}$ \\
\hline $\mathrm{C} 2$ & $89.1 \pm 6.41^{\mathrm{a}}$ & $72.4 \pm 0.15^{\mathrm{a}}$ \\
\hline $\mathrm{C} 3$ & $88.2 \pm 0.75^{\mathrm{a}}$ & $72.9 \pm 5.50^{\mathrm{a}}$ \\
\hline C4 & $89.3 \pm 7.42^{\mathrm{a}}$ & $74.1 \pm 1.04^{\mathrm{a}}$ \\
\hline \multicolumn{2}{|c|}{ Means followed by the same letter in a column are not } \\
significantly different at $\mathrm{P} \leq 0.05$
\end{tabular}

\section{Discussion}

\subsection{Composting process}

The dark brown colour, the relatively dry and uniform structure, the lack of odours, the ambient temperature $\left(25^{\circ} \mathrm{C}\right)$ observed from the produced composts and its texture (soil's texture) reflect respectively the degree of stability or maturity of those composts. This is in accordance with the results obtained by [15], who found that, the above characteristics of the compost generally indicate that the composts obtained at the end of the composting process are stable and mature.

The lack of odours noticed respectively during the composting process and at the end of the process might be due to the absence of some volatile compounds such as $\mathrm{NH}_{3}$ [19] organic acids, and some of the sulfur-containing compounds and the increased aeration that took place during the composting process. [19]. 
Besides, it may be the result of the absence of those intermediate compounds that had been decomposed during the thermophile phase of composting [19]. Moreover, that lack of odour should be also explained by the acidity of the compost piles $\mathrm{pH}$, which was (5.7). It could also be explained by the initial value of cassava peels $\mathrm{C} / \mathrm{N}$ ration (30.13), which did not allow the underutilization of $\mathrm{N}$, during which the excess is usually lost to the atmosphere as ammonia or nitrous oxide. That is in accordance with the [11] and [20] who showed that a $\mathrm{C}: \mathrm{N}$ ratio of less than 20:1 leads to underutilization of $\mathrm{N}$ and the excess may be lost to the atmosphere as ammonia or nitrous oxide.

\subsection{Physical and chemical properties}

The salinity of a compost is measured by its electrical conductivity, which greatly depends on the nutrient content of the compost and determines the phytotoxicity of a compost. Therefore, the increase of EC regarding the amount of cassava peels, which was composted, could be explained by the process of organic matter mineralisation, which always takes place during the composting process [21] [22]. That increase might also be the result of the maturation phase, which is the last phase of the process of composting, during which there is a production of organic acids and soluble salt. Moreover, it could also be explained by the slight amount of $\mathrm{Mg}^{2+} ; \mathrm{Ca}^{2+} ; \mathrm{K}^{+}$and $\mathrm{Na}^{+}$in the produced composts. [22] [23] [24]. As a result, a great amount of cassava peels might increase the salinity of the final product that might cause osmotic problems and affects water intake ability [22]. However, the value of the electrical conductivity of each produced compost was below the value that might cause a toxical effect on plants $(3,7$ à $8,8 \mathrm{mS} / \mathrm{cm})$ [25]. The few concentration of $\mathrm{Cu}$ from the produced composts could be explained by their absence from the composted cassava peels.

The slight increase of $\mathrm{pH}$ from the obtained composts (C1, C2, C3, and C4) should be explained by the presence of a thermophilic phase in which there is the degradation of organic acids, produced during the acidophilic phase, which allows a phenomenon of alkalization of the compost, which is increased by the mineralization of the soil's nitrogen [22] [26] [27] [28]. That increase in $\mathrm{pH}$ may be also attributed to the lack of production of some organic acids [22]. It could also be the lack of $\mathrm{CO}_{2}$ mineralization of organic material [29].

The increase of the total nitrogen from C2, C3, and $\mathrm{C} 4$ at the end of the process of composting could be the result of two main reactions that took place during the process: the reaction of mineralization and nitrification [30], during which there is the production of $\mathrm{NH}_{4}{ }^{+}$and $\mathrm{NO}_{3}{ }^{+}$. It might also be due to respectively the lack of $\mathrm{NH}_{3}$ volatilization and the absence of three other reactions (incomplete denitrification, complete denitrification) during which there is the formation of $\mathrm{N}_{2} \mathrm{O}$ and $\mathrm{N}_{2}$ that can be released into the atmosphere [30]. Moreover, the increase of the total nitrogen from $\mathrm{C} 2, \mathrm{C} 3$, and $\mathrm{C} 4$ could also be explained by the fact that, under the $\mathrm{pH}$ conditions (less than 8.4) [31], the NH3-N form is difficult to be volatilized to the gas form and lost [30].

The decrease of $\mathrm{P}$ in the different composts could be explained by the fact that the composting may affect the distribution of $\mathrm{P}$ fractions, and the lack of phosphate solubilizing microbes that might solubilize insoluble $\mathrm{P}$ composts [22]. It might also result in the lower presence of microbial activity related to organic acids production lead to the solubilization of precipitated inorganic P [22] [31].

The drop of $\mathrm{C} / \mathrm{N}$ rations at the end of the composting process could be the result of the lack of nitrogen volatilisation (i.e. increasing nitrogen content) [22] [32]. It may be also due to the release of the carbon in the form of $\mathrm{CO}_{2}$, and it would imply the level of humification of the organic matter [32]. Studies done previously, have indicated that a $\mathrm{C} / \mathrm{N}$ ratio between 10 and 21 at the end of composting is an indicator of compost maturity [22] [32]. In this study, the composts produced meet this criterion.

One of the most commonly used and sensitive biological indicators for assessing the 
phytotoxicity and maturity of compost is the value of the GI [22] [33]. The results obtained from the phytotoxicity test demonstrated that the composts had GIs $\geq 80 \%$. Those results showed that the produced composts were mature and devoid of any toxic effect. Those results are in accordance with the result obtained by [34] [35] [36] [37] [38] and[22], who showed that GI values of $80 \%$ are indicative of mature compost with no phytotoxic effect. On the other hand, the results of the GI are also in the same line with those obtained from the gemination test where all the samples ( B1, B2, B3 and B4) of the composts had the rate of germination greater than $80 \%$. This could be explained by the fact that the composts produced had a $\mathrm{pH}$ ( 6.5) and good EC that allow the normal germination of sweet pepper seeds and their richness in mineral nutrients. It may be also due to the absence of harmful microorganisms.

\subsection{Microbial biomass}

The increasing quantity of cassava peels had positive effects on bacterial and fungal populations because it did not impair or change the imbalance that is usually observed at the end of the composting process in which the proportion of fungi increases, while bacterial numbers decline. [39] That increase of fungi population and decrease of the bacterial population could be due to the fact that during the maturation phase, compounds that are not further degradable, such as lignin-humus complexes and cellulose, are formed and become predominant [38]-[39]. Such kind of compounds is much more degradable by the fungi population than bacterial population [38]. It may also be explained by the water potential decreases, which is an advantage for fungi. On the other hand, the lack of significant difference, respectively in between the proportion of fungi and bacterial biomass, observed from the produced composts could be due to the relative salt concentrations (EC) that have been noticed. [40] [41] [42]. Therefore the important presence of this total microflora would reflect the maturity and ecocompatibility of the composts [22].

\section{Conclusion}

This study showed that cassava peels are good substrate that can be used to produce a good quality compost. The electrical conductivities of 1.49 to $1.92 \mathrm{mS} / \mathrm{cm}$ that were recorded from vrious composts, respected the stantards value $(3,7-8,8 \mathrm{mS} / \mathrm{cm})$ and were below the phytotoxic levels. The $\mathrm{pH}$, was nearly neutral, favorable to the cultivation of fruits and vegetables. Composts were rich in minerals and poor in heavy metals. In addition, the produced composts showed a germination index and the rate of germintion of sweet pepper seeds were greater than $80 \%$, indicating the absence of phytotoxicity. The increased amounts of cassava peels did not modify the process of composting and increased the fungal and bacterial populations. The compost of cassava peels could be recommended as organic fertilizer to remediate soil fertility and base deficiency, increase the soil microbial biamass and reduce the environmental pollution. The implimentation of cassava peels waste as compost is a contribution to waste valorization and also represent a suitable alternative to mineral fertilizers for poor resource farmers.

\section{Declarations}

\subsection{Acknowledgements}

The authors thank Ngono Nda Jacqueline Betty for supplying the cassava peels, the Agricultural. Research Institute for Development (IRAD) Cameroon for assistance with the chemical analysis and microbial biomass analysis.

\subsection{Competing Interests}

The authors declared that no conflict of interest exist in this publication.

\section{How to Cite this Article:}

O. Dieudonne, . J. Nguefack, J. B. . Dongmo Lekagne, C. . Dakole Daboy, and . G. Ndonkeu Mangoumou, "The Potential of Cassava (Manihot esculenta Crantz) Peels as an Organic Fertilizer", Int. Ann. Sci., vol. 10, no. 1, pp. 107-117, Jan. 2021.

\section{References}

[1] N. K. Kortei, , V. P. Dzogbefia, and M. Obodai. "Assessing the effect of composting cassava peel based substrates on the yield, nutritional quality, and physical characteristics of Pleurotus ostreatus (Jacq. ex Fr.) Kummer." Biotechnology 


research international 2014
http://dx.doi.org/10.1155/2014/571520

[2] M. M. Elise Stephanie, and L. Dapeng. "Gap Analysis of Cassava Sector in Cameroon" Vol:6, No:11, 2012. https:// doi.org/10.5281/zenodo.1058349.

[3] S. Suci, Q. K. Denis, M. Dian and Masruri, "Physical Properties and Characterization of Cassava Peel Waste Modified by Esterification"Vo:6; No : 3, pp, 255-260; Sep, 2017. DOI: 10.21776/ub.jpacr.2017.006.03.346

[4] Aro, S. Ol, V. A. Aletor, O. O. Tewe, and J. O. Agbede. "Nutritional potentials of cassava tuber wastes: A case study of a cassava starch processing factory in south-western Nigeria." Livestock Research for Rural Development Vo:22, no. 11: $\quad$ pp, 42-47. Nov,2010. http://www.lrrd.org/lrrd22/11/aro22213.htm

[5] AA, Odunfa SA Olabiwoninu, and S. A. Odunfa. "Enhancing the production of reducing sugars from cassava peels by pretreatment methods." International J. Sci. Technol Vo:2, no. 9, pp,650-657. Sep,2012.

[6] Wongskeo, Pitcha, R. Pramoch, and C. Sumaeth. "Production of glucose from the hydrolysis of cassava residue using bacteria isolates from thai higher termites." J. Word Acad. Sci. Eng. Technol, Vo:64: pp.353-35, Apr,2012.

[7] K. Adebayo, and M. A. Sangosina. "Processors'perception of the effectiveness of some cassava processing innovations in Ogun State, Nigeria". No. 814-2016-52609. 2005. DOI: 10.22004/ag.econ.54395

[8] O.F. Odediran, O.R. Ashimolowo, C. L. Sodiya, L. O. Sanni, K. Adebayo, W.G. Ojebiyi, and Q. S. Adeoye,"Awareness of Cassava Peel Utilization Forms among Cassava Processors in Rural Communities of Southwest, Nigeria." International Journal of Applied Agriculture and Apiculture Research, Vo:11. No.1-2, pp. 93-102, 2015.

[9] E.A. Makinde., and A. W. Salau. "Fortified cassava peel compost amendment for Amaranthus: influence on plant growth, nutrients uptake and on soil nutrient changes." Journal of Plant Nutrition Vo.40. No.5, pp. 645-655. Mar. 2017. https://doi.org/10.1080/01904167.2016.1245328

[10] T. Kuba, A. Tschöll, C. Partl, K. Meyer, and H. Insam. "Wood ash admixture to organic wastes improves compost and its performance." Agriculture, ecosystems and environment $\quad 127.1-2 \quad$ (2008): $43-49$. https://doi.org/10.1016/j.agee.2008.02.012

[11] R. V. Misra, R. N. Roy, and H. Hiraoka. On-farm composting methods. Rome, Italy: UN-FAO, 2003.

[12] J. M. Bremner, "Determination of nitrogen in soil by the Kjeldahl method," The Journal of Agricultural Science, vol. 55, no. 1, pp. 11-33, 1960. DOI: https://doi.org/10.1017/S0021859600021572

[13] S.M. Tiquia., N. F. Y. Tam, and I. J. Hodgkiss. "Effects of composting on phytotoxicity of spent pig-manure sawdust litter." Environmental pollution Vo. 93.No.3 pp.249-256. 1996. https://doi.org/10.1016/S0269-7491(96)00052-8

[14] International Rules for Seed Testing (ISTA), "Seed Science and Technology" Volume 24, Supplement, Rules, 1996

[15] St. Martin, C. C., Bekele, I., Eudoxie, G. D., Bristol, D., Brathwaite, R. A., and Campo, K. R. "Modelling response patterns of physico-chemical indicators during high-rate composting of green waste for suppression of Pythium ultimum." Environmental technology; vol.35,no.5, pp.590601 ; $\quad$ Mar. 2014. https://doi.org/10.1080/09593330.2013.839719

[16] M., G. W., and S. Funder. "Practical Mycology. Manual for Identification of Fungi". Mycologia, vol. 47, no.1, pp. 153,1955 .

https://www.cabdirect.org/cabdirect/abstract/19541100542

[17] M., G. W., and S. Funder. "Practical Mycology. Manual for Identification of Fungi". Mycologia, vol. 47, no.1, pp. 153,1955 .

https://www.cabdirect.org/cabdirect/abstract/19541100542

[18] L. Zhang, J. Zhang, G. Zeng, H. Dong, Y. Chen, C. Huang, Y. Zhu, R. Xu, Y. Cheng, K. Hou and W. Cao. "Multivariate relationships between microbial communities and environmental variables during co-composting of sewage sludge and agricultural waste in the presence of PVPAgNPs". Bioresource technology. no.1, vol. 261: pp.10-18, Aug 2018. https://doi.org/10.1016/j.biortech.2018.03.089

[19] H. Kassa, H. Suliman, and T. Workayew. "Evaluation of composting process and quality of compost from coffee byproducts (Coffee Husk \& Pulp)." Ethiopian Journal of Environmental Studies and Management Vo.4 No..4, 2011. DOI: $10.4314 /$ jesm.v4i4.2

[20] K. Azim, B. Soudi, S. Boukhari, C. Perissol, S. Roussos, and I. Thami Alami."Composting parameters and compost quality: a literature review." Organic Agriculture vol. 8, No.2, pp.141-158. Jan,2018. https://doi.org/10.1007/s13165017-0180-z

[21] C. Francou . "Stabilization of organic matter during composting of urban waste: Influence of the nature of the waste and the composting process - Search for relevant indicators". PhD thesis, National Agronomic Institute ParisGrigon, pp 289. Dec, 2003

[22] B. P. Bougnom, O. Dieudonne, and A. M. Sontsa-Donhoung, "Evaluation of Wood Ash as Additive for Cow Manure Composting”, Int. Ann. Sci., vol. 9, no. 1, pp. 100- 110, Mar. 2020. DOI: https://doi.org/10.21467/ias.9.1.100-110

[23]Y Avnimelech, M. Bruner, L. Ezrony, R. Sela and M.Kochba, "Stability indexes for municipal solid waste compost." Compost Science and Utilization Vo.4, No. 2, pp.13-20. Mar, 1996. https://doi.org/10.1080/1065657X.1996.10701825

[24] L. Wu, L. Q. Ma, and G. A. Martinez, "Comparison of methods for evaluating stability and maturity of biosolids compost," Journal of Environmental Quality, vol. 29, no. 2, pp. 424-429, 2000. https://doi.org/10.2134/jeq2000.00472425002900020008x

[25] M. Larbi. "Influence of the quality of composts and their extracts on the protection of plants against fungal diseases." PhD thesis., University of Neuchâtel, 2006.

[26] J. Wu, Y. Zhao., F. Wang., X. Zhao., Q. Dang., T. Tong. and Z. Wei.. "Identifying the action ways of function materials in catalyzing organic waste transformation into humus during chicken manure composting." Bioresource Technology Vo.303 pp.122927. May.2020 https://doi.org/10.1016/j.biortech.2020.122927

[27] Z. Xu., G. Li., N. Huda., B. Zhang., M. Wang., and W. Luo,. "Effects of moisture and carbon/nitrogen ratio on gaseous emissions and maturity during direct composting of cornstalks used for filtration of anaerobically digested manure centrate." Bioresource Technology Vo. 298, pp. 122503 , Feb. 2020 https://doi.org/10.1016/j.biortech.2019.122503

[28] B. P. Bougnom, A. M. Sontsa-Donhoung, O. Dieudonne, P. M. Françoise X. Etoa., "Evaluation of wood ash as additive for green waste composting", International Journal of Agronomy and Agricultural Research, Vol. 13, No. 5, p. 3545, 2018.

[29] Z. Usmani, V. Kumar, R. Rani, R, P. Gupta, and A. Chandra "Changes in physico-chemical, microbiological and 
Onguene Dieudonne et al., Int. Ann. Sci.; Vol. 10, Issue 1, pp: 107-117, 2021

biochemical parameters during composting and vermicomposting of coal fly ash: a comparative study". International Journal of Environmental Science and Technology. Vol. 16, no.8, pp. 4647-4664. Aug, 2019. https://doi.org/10.1007/s13762-018-1893-6

[30] Cáceres, Rafaela, K. Malińska, and O. Marfà. "Nitrification within composting: a review." Waste Management No.72 : pp.119-137,

Feb,2018. https://doi.org/10.1016/j.wasman.2017.10.049

[31] Chowdhury, Md Albarune, A. de Neergaard, and J. L. Stoumann Jensen. "Potential of aeration flow rate and biochar addition to reduce greenhouse gas and ammonia emissions during manure composting." Chemosphere, No.97, pp.16-25,

Feb.2014. https://doi.org/10.1016/j.chemosphere.2013.10.030

[32] L. Liu, S. Wang, X. Guo, T. Zhao, and B. Zhang, "Succession and diversity of microorganisms and their association with physicochemical properties during green waste thermophilic composting". Waste Management, vol. 73, no.1, pp. 101-112, Mar 2018. https://doi.org/10.1016/j.wasman.2017.12.026

[33] J. Bohacz, "Composts and Water Extracts of Lignocellulosic Composts in the Aspect of Fertilization, Humus-Forming, Sanitary, Phytosanitary and Phytotoxicity Value Assessment." Waste and Biomass Valorization vol.10, no.1, pp.2837-2850, Oct, 2018. https://doi.org/10.1007/s12649018-0334-6

[34] N. Liu, T. Hou, H. Yin, L. Han, and G. Huang, "Effects of amoxicillin on nitrogen transformation and bacterial community succession during aerobic composting", Journal of Hazardous Materials. vol. 362, pp. 258-265, Jan, 2019. https://doi.org/10.1016/j.jhazmat.2018.09.028

[35] T.H. DeLuca, and D. K. DeLuca, "Composting for feedlot manure management and soil quality." Journal of Production Agriculture vol. 10, no. 2, pp. 235-241, 1997. https://doi.org/10.2134/jpa1997.0235

[36]Y. Luo, J. Liang, G. Zeng, M. Chen, D.Mo, G. Li, and D. Zhang, (2018). "Seed germination test for toxicity evaluation of compost: Its roles, problems and prospects". Waste Management, vol. 71, pp.109-114, 2018. https://doi.org/10.1016/j.wasman.2017.09.023

[37] J. Jiang, K. Kang, D. Chen, and N. Liu, "Impacts of delayed addition of N-rich and acidic substrates on nitrogen loss and compost quality during pig manure composting". Waste Management, vol. 72, pp. 161-167, 2018. https://doi.org/10.1016/j.wasman.2017.11.025

[38] de Bertoldi, M. de, G. et Vallini, and A. Pera. "The biology of composting: a review." Waste Management and Research Vo.1, no.2, pp.157-176, Jun.1983. https://doi.org/10.1016/0734-242X(83)90055-1

[39] C. Gómez-Silván., G. L. Andersen., C. Calvo., and E. Aranda. "Assessment of bacterial and fungal communities in a full-scale thermophilic sewage sludge composting pile under a semipermeable cover." Bioresource Technology Vo.1, No. 298, pp.122550. Feb.2020. https://doi.org/10.1016/j.biortech.2019.122550

[40] A. Muscolo, T. Papalia, G. Settineri, C. Mallamaci and A. Jeske-Kaczanowska, "Are raw materials or composting conditions and time that most influence the maturity and/or quality of composts? Comparison of obtained composts on soil properties", Journal of cleaner production vol.195, no. 10, $\quad$ pp. 93-101, Sep 2018. https://doi.org/10.1016/j.jclepro.2018.05.204

[41] N. Liu, T. Hou, H. Yin, L. Han, and G. Huang, "Effects of amoxicillin on nitrogen transformation and bacterial community succession during aerobic composting", Journal

of Hazardous Materials. vol. 362, pp. 258-265, Jan, 2019. https://doi.org/10.1016/j.jhazmat.2018.09.028

[42] C. Asquer, G. Cappai, A. Carucci, G.De Gioannis, A. Muntoni, M. Piredda, and D. Spiga, "Biomass ash characterisation for reuse as additive in composting process". Biomass and Bioenergy, vol. 123, pp. 186-194, 2019. https://doi.org/10.1016/j.biombioe.2019.03.001

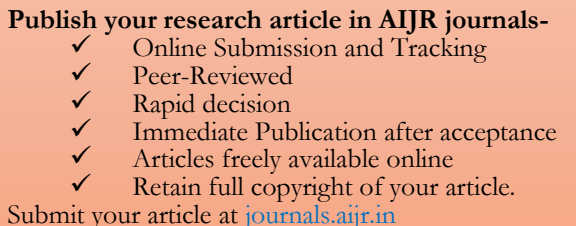

Submit your article at journals.aijr.in

Publish your books with AIJR publisher$\checkmark$ Publish with ISBN and DOI. Publish Thesis/Dissertation as Monograph Publish Book Monograph. Publish Edited Volume/ Book. Publish Conference Proceedings Retain full copyright of your books. Submit your manuscript at books.aijr.org 